University of Nebraska - Lincoln

DigitalCommons@University of Nebraska - Lincoln

USDA Forest Service / UNL Faculty Publications U.S. Department of Agriculture: Forest Service -National Agroforestry Center

$12-2008$

\title{
Decay of Aspen (Populus tremuloides Michx.) Wood in Moist and Dry Boreal, Temperate, and Tropical Forest Fragments
}

\author{
Grizelle Gonzalez \\ USDA Forest Service, International Institute of Tropical Forestry, ggonzalez@fs.fed.us \\ William A. Gould \\ International Institute of Tropical Forestry GIS and Remote Sensing Laboratory,wgould@fs.fed.us \\ Andrew T. Hudak \\ Rocky Mountain Research Station, ahudak@fs.fed.us \\ Teresa Nettleton-Hollingsworth \\ USDA FS, Boreal Ecology Cooperative Research Unit, thollingsworth@fs.fed.us
}

Follow this and additional works at: https://digitalcommons.unl.edu/usdafsfacpub

Gonzalez, Grizelle; Gould, William A.; Hudak, Andrew T.; and Nettleton-Hollingsworth, Teresa, "Decay of Aspen (Populus tremuloides Michx.) Wood in Moist and Dry Boreal, Temperate, and Tropical Forest Fragments" (2008). USDA Forest Service / UNL Faculty Publications. 175.

https://digitalcommons.unl.edu/usdafsfacpub/175

This Article is brought to you for free and open access by the U.S. Department of Agriculture: Forest Service -National Agroforestry Center at DigitalCommons@University of Nebraska - Lincoln. It has been accepted for inclusion in USDA Forest Service / UNL Faculty Publications by an authorized administrator of DigitalCommons@University of Nebraska - Lincoln. 


\section{Decay of Aspen (Populus tremuloides Michx.) Wood in Moist and Dry Boreal, Temperate, and Tropical Forest Fragments}

In this study, we set up a wood decomposition experiment to i) quantify the percent of mass remaining, decay constant and performance strength of aspen stakes (Populus tremuloides) in dry and moist boreal (Alaska and Minnesota, USA), temperate (Washington and Idaho, USA), and tropical (Puerto Rico) forest types, and ii) determine the effects of fragmentation on wood decomposition rates as related to fragment size, forest age (and/ or structure) and climate at the macro- and meso-scales. Fragment sizes represented the landscape variability within a climatic region. Overall, the mean small fragments area ranged from 10-14 ha, medium-sized fragments 33 to 60 ha, and large fragments $100-240$ ha. We found that: i) aspen stakes decayed fastest in the tropical sites, and the slowest in the temperate forest fragments, ii) the percent of mass remaining was significantly greater in dry than in moist forests in boreal and temperate fragments, while the opposite was true for the tropical forest fragments, iii) no effect of fragment size on the percent of mass remaining of aspen stakes in the boreal sites, temperate dry, and tropical moist forests, and iv) no significant differences of aspen wood decay between forest edges and interior forest in boreal, temperate and tropical fragments. We conclude that: i) moisture condition is an important control over wood decomposition over broad climate gradients; and that such relationship can be non linear, and ii) the presence of a particular group of organism (termites) can significantly alter the decay rates of wood more than what might be predicted based on climatic factors alone. Biotic controls on wood decay might be more important predictors of wood decay in tropical regions, while abiotic constraints seems to be important determinants of decay in cold forested fragments.

\section{INTRODUCTION}

North American landscapes can be viewed as a mosaic of forested and non forested fragments that vary from region to region depending on climate, land use, and fire history. Accelerating rates of fragmentation in a variety of forest types creates increasingly complex forest environments nationwide. Many public lands, including National Parks and Forests, military bases, parks, and riparian buffer zones, contain or are surrounded by forest fragments that widely vary in structure, function, biodiversity, habitat quality, and susceptibility to fires. The effect of edges created by habitat fragmentation is a prominent and recurring theme in many studies of conservation biology $(1,2)$. Furthermore, it is widely acknowledged that forest structure and the spatial morphology and distribution of fragments can significantly affect not only fuel accumulation and fire frequency (3-5), but also ecological processes $(6,7)$. However, little is known about how decay rates of wood (fuel loads) vary within and among fragments along broad climatic gradients.
From the boreal to the tropical life zones, woody plants represent the most characteristic feature of forests (8). Depending on the forest type and its developmental stage, the portion of aboveground biomass represented by woody tissue can range from 10 to $80 \%(9-11)$. In the long-term, woody tissues are relevant to the global balance of atmospheric $\mathrm{CO}_{2}$ through the sequestration of large amounts of carbon $(12,13)$. It is therefore not surprising that many conservation and management strategies recommend minimum amounts, and specific quality and distribution of wood in forests $(8,14-17)$, and recognize wood decomposition as a key ecological process (18).

In this study, we set up a wood decomposition experiment to i) quantify the percent of mass remaining, decay constant and performance strength of a common substrate in boreal, temperate and tropical forests, and ii) determine the effects of fragmentation on wood decomposition rates as related to fragment size, forest age (and/or structure) and climate at the macro- and meso-scales. Three main questions were: $i$ ) Are decay rates of a common wood substrate higher at the forest edges than the center of the forest fragments? ii) Will decay rates of a common wood substrate vary among forest fragments of different sizes? iii) Are decay rates higher in older/closed canopy fragments than in younger/open canopy ones? We expect decay rates will be higher in wet/warm climates than in cold/dry environments.

\section{METHODS}

\section{Study Area Descriptions}

Study areas represent dry and moist boreal (Alaska and Minnesota, USA), temperate (Washington and Idaho, USA), and tropical (Puerto Rico) forest types (Fig. 1). The dry boreal forest fragments sampled are located in interior Alaska on the Fairbanks North Star Borough with many of the sites in the Bonanza Creek Experimental Forest. Mean latitude of dry boreal forests is 64.6 degrees North (19). The moist boreal forest fragments sampled are located in north central Minnesota in the Chippewa National Forest within Itasca and Cass counties. Mean latitude of moist boreal forests is 49.5 degrees North (19). The dry boreal forest fragments sampled are more coniferous than deciduous, interspersed by rivers (20) and commonly fragmented by roads, power lines and cleared fields (Fig. 2); while the moist boreal forest fragments sampled are more deciduous than coniferous and more interspersed by lakes (20). Plots in the boreal forests were located in spruce (Picea sp.) stands in Alaska and primarily pine (Pinus sp.) stands in Minnesota. Mean annual precipitation for boreal dry and moist forests is 359 and $668 \mathrm{~mm}$, respectively (19). Mean annual median temperature for boreal dry and moist forests is -2.9 and $2.4^{\circ} \mathrm{C}$, respectively (19).

The temperate forest fragments (both dry and moist) sampled are in coniferous forests located on Native American Tribal lands in the Interior Northwest: the temperate dry forest fragments are located in the Spokane Indian reservation in eastern Washington in Stevens county, while the temperate 


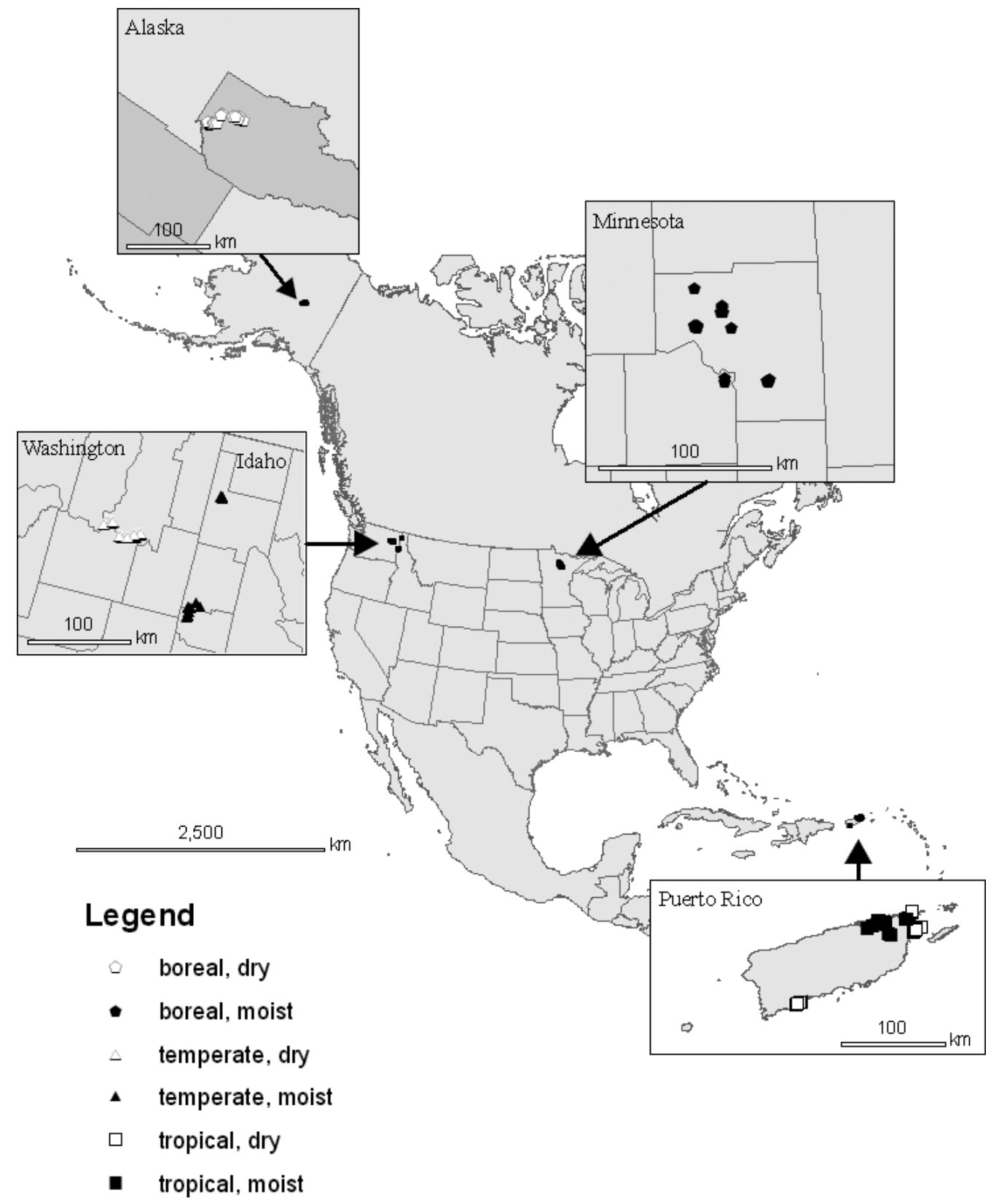

Figure 1. Study areas of dry and moist boreal (Alaska and Minnesota, USA), temperate (Washington and Idaho, USA), and tropical (Puerto Rico) forest fragments.

moist forest fragments are located in the Coeur d'Alene Indian Reservation in northern Idaho in Bonner, Kootenai, and Benewah counties. Mean latitude of dry and moist temperate forests is 44.8 and 47.8 degrees North, respectively (19). The temperate dry forest is dominated by Pinus ponderosa (ponderosa pine) and on moister aspects, Pseudotsuga menziesii (Douglas-fir), while the temperate moist forest is more species-rich mixed conifer forest (20). Mean annual precipitation for temperate dry and moist forests is 682 and $1017 \mathrm{~mm}$, respectively (19). Mean annual median temperature for temperate dry and moist forests is 7.2 and $6^{\circ} \mathrm{C}$, respectively (19). Temperate forests are commonly fragmented due to forest management practices (with associated roads), agricultural fields, and some mining (Fig. 3).

The tropical moist forest fragments sampled in Puerto Rico (18.3 degrees North) occur mainly on private land on the northeastern side of the island; the majority of tropical dry forest fragments sampled are located in southwestern Puerto Rico within the Guánica Dry Forest Reserve and a minority in the eastern part of the island within the military grounds of the US Naval Station of Roosevelt Roads (18.1 degrees North) (Fig. 1). Mean annual precipitation for tropical dry and moist forests is 1328 and $1992 \mathrm{~mm}$, respectively (19). Mean annual median temperature for tropical dry and moist forests is 25.8 and $25.4^{\circ} \mathrm{C}$, respectively (19). Forest vegetation is primarily broad leaf evergreen in the tropical moist areas, and broad leaf semi-deciduous in the tropical dry forests of Puerto Rico (21). Forest fragmentation in Puerto Rico is strongly associated with anthropogenic disturbances (e.g., roads, urban development) and to a lesser extent with agricultural practices (e.g., cattle pastures).

\section{Field Plots}

In 2002-2003, field campaigns were conducted in Puerto Rico, Washington, Idaho, Minnesota, and Alaska to measure forest attributes along forest edge gradients. Forest edges caused by roads, timber harvest, agriculture, or urbanization were sampled in the field across the full range of forest structure types observed in each study landscape. A forest edge was defined as a distinct non-forest/forest transition as observed in the field (20). Forest attributes (e.g., woody fuels, number of tree stems, tree basal area, and species richness, percent canopy cover among other variables; see Gould et al. [19] and Meddens 

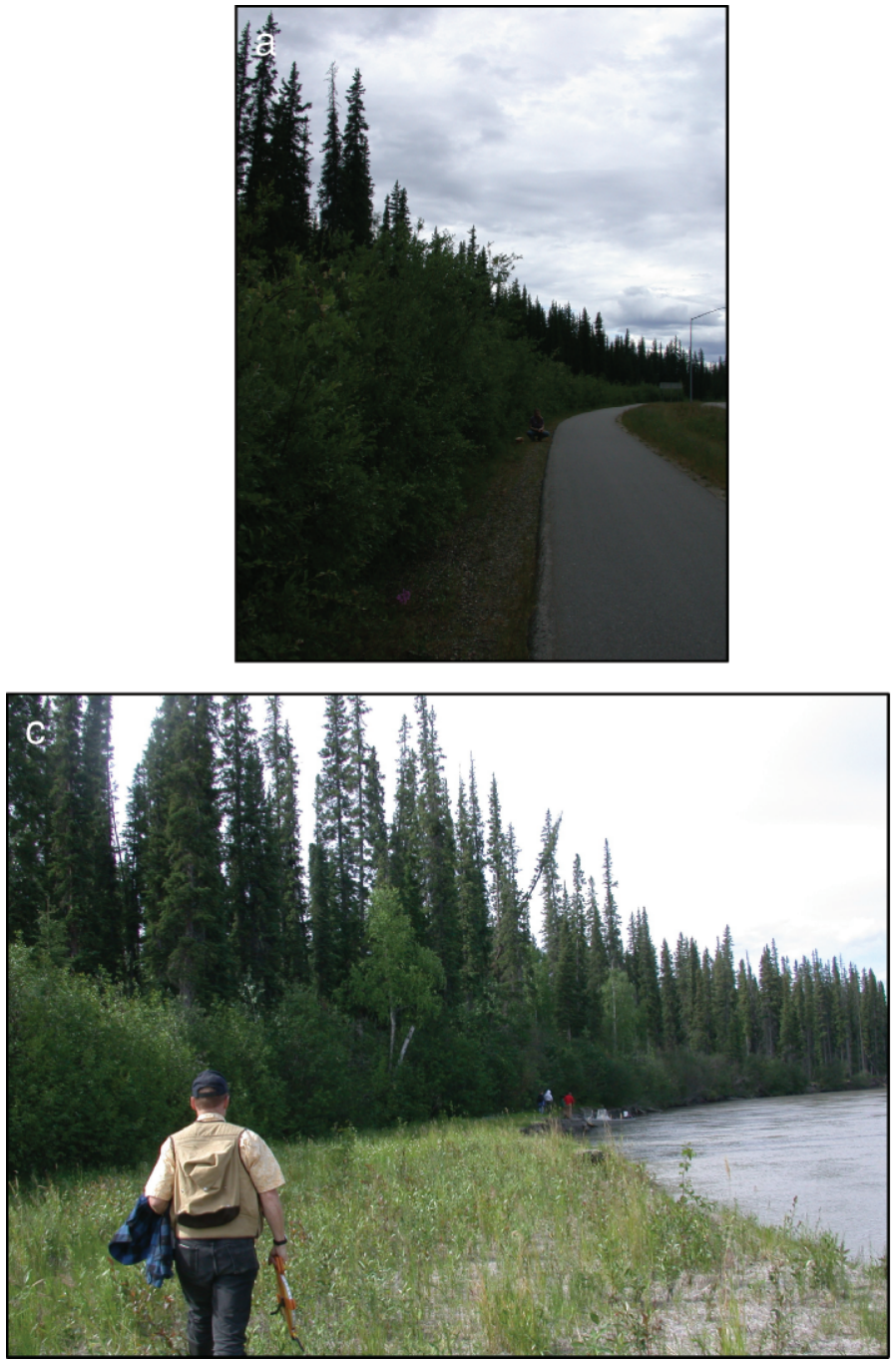

Figure 2. Boreal forests in Alaska are more coniferous than deciduous, and commonly fragmented by a) roads, b) cleared fields, c) rivers, and d) power lines.

et al. [20] for methodological details of forest attribute data) were collected from plots systematically located along a $60 \mathrm{~m}$ linear transect oriented perpendicular to the forest edge. Each transect consisted of a non forested plot centered $5 \mathrm{~m}$ outside the forest edge, an edge plot centered $5 \mathrm{~m}$ inside the forest edge, and three forest (interior) plots 15,35 , and $55 \mathrm{~m}$ inside the forest edge. A total of 720 transects were established across dry and moist of forest fragments of boreal, temperate and tropical climates. Further, field transects represented areas of different forest fragment sizes (small, medium and large) and stand age and/or structure (young vs. old and/or open vs. closed canopy).

Field characterization, aerial photography, and ancillary data were used to select fragment forest type (dry and moist as well as open/young and close/older), size (small, medium, and large) and to determine actual area in hectares. To help determine fragment area we used for Puerto Rico, digital information on the main and secondary roads from the Puerto Rico Department of Transportation and Public Works, the PRGAP 2003 vegetation map (22), and US Army Corps of Engineers 2004 DOQQ (Digital Orthophoto quarter-quads) $1 \mathrm{~m}$ resolution air photos. For Idaho, we used the main and secondary roads from the Idaho Transportation Department. In Washington, data used included state routes from the Washington State Department of Transportation. In Minnesota, we used the main roads from the Minnesota Department of Transportation, Survey and Mapping, and USGS DOQQ 1990 air photos downloaded from The National Map Seamless
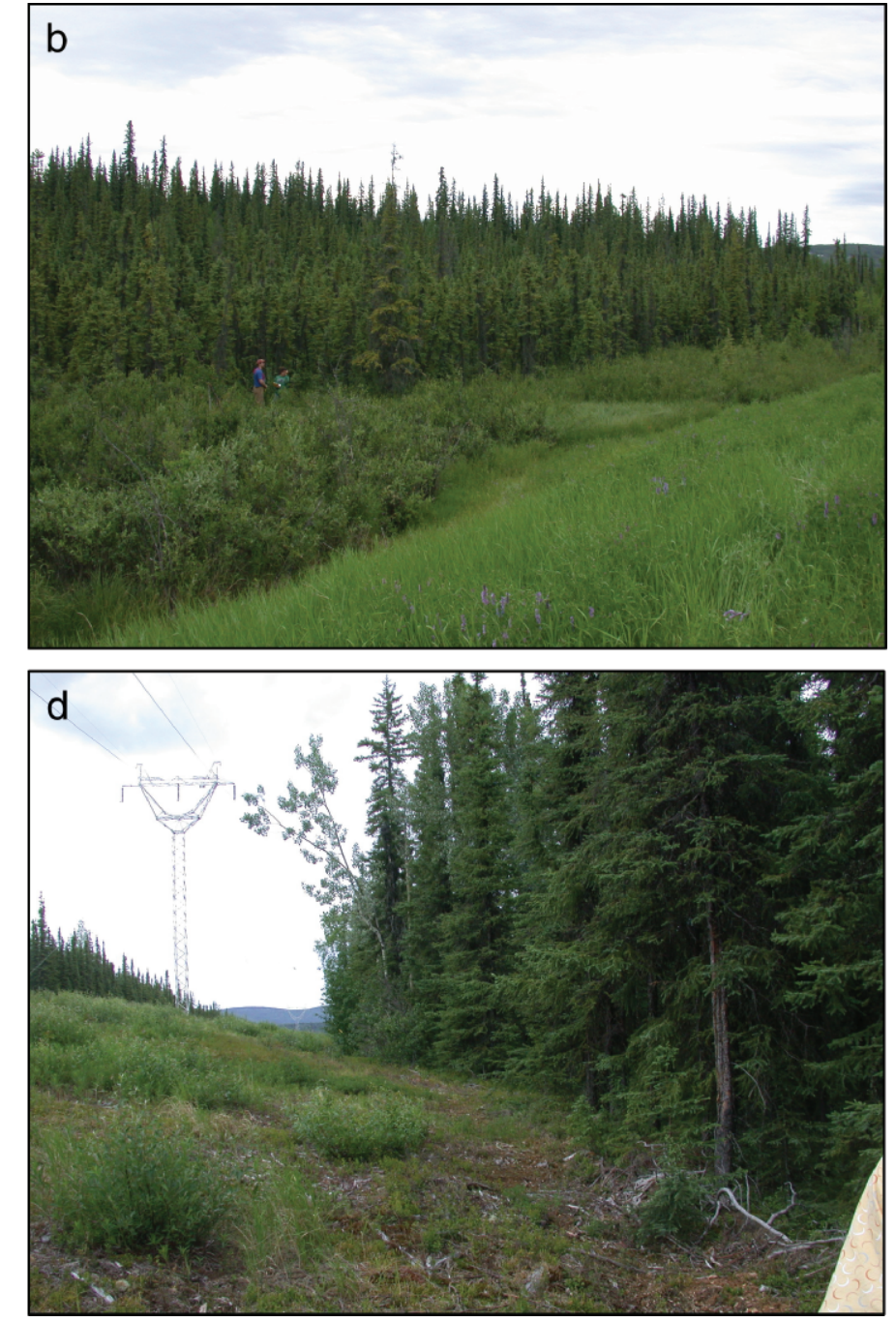

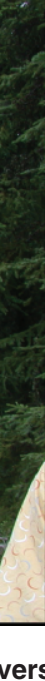

Server (23). For Alaska, the USGS National Land Cover Database 2001, and streams and roads from the National Atlas Seamless Server were used (23).

Fragments representing younger (or open canopy) stands had more trees per hectare, and lower: canopy cover, basal area, tree DBH and height (see Gould et al. [19] for actual data). In the Alaskan sites, the open canopy/younger forest fragments were black spruce stands (Picea mariana) on permafrost, while close canopy/older forest fragments were white spruce (Picea glauca) on non permafrost, well-drained soils. Black spruce stands on permafrost are slow growing and may be older than white spruce stands; yet structurally they are similar to younger stands (relatively smaller DBH, and tree height, etc.). Fragment sizes represented the landscape variability within a climatic region. Overall, the mean small fragments area ranged from 10 14 ha, medium-sized fragments 33 to 60 ha, and large fragments 100-240 ha.

\section{Wood Decomposition Experiment}

During June 5-23, 2003, an experiment was set up in a subset of the above mentioned field transects to look at the effect of climate (boreal, temperate, tropical), moisture (dry and moist forests), forest fragment size (small, medium and large), stand age and/or structure (open canopy/young and close canopy/ older), and position along the forest edge gradient/transect (outside (non-forest plot centered $5 \mathrm{~m}$ outside the forest edge), 

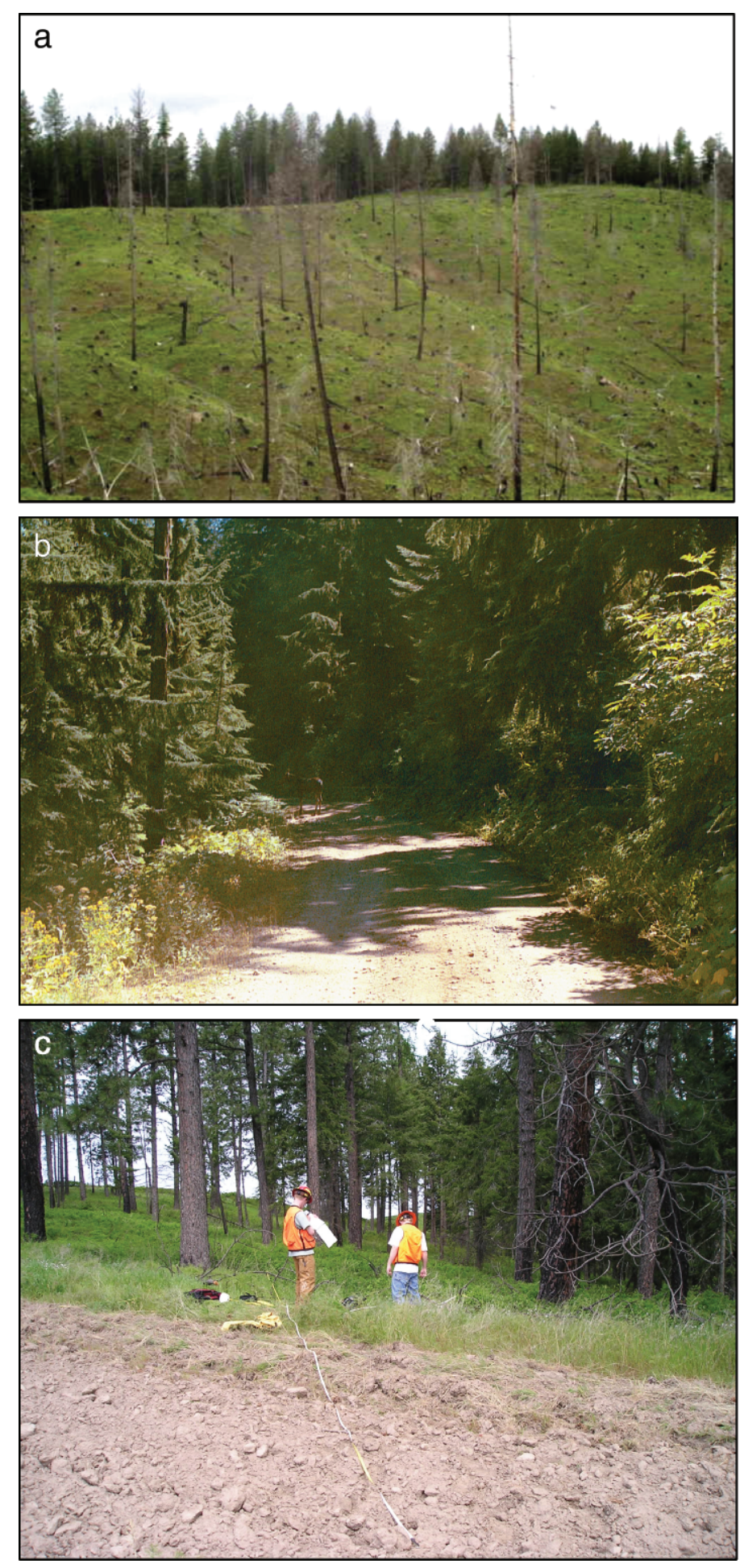

Figure 3. Temperate forest fragments are commonly fragmented due to logging management practices. (a) timber harvest and (b) associated roads, and agricultural fields (c).

edge ( $5 \mathrm{~m}$ inside the forest edge), and interior of the forest fragment $(55 \mathrm{~m}$ inside the forest edge) on the decay of a common wood substrate. These 108 site conditions were replicated 3 times. Thus, a grand total of 324 plots 3 climate $\times 2$ moisture $\times 3$ size $\times 2$ structure $\times 3$ position $\times 3$ replicates $=$ 324) were established for the wood decomposition experiment.

Within each plot (approx. $1 \times 1 \mathrm{~m}$ ), 14 stakes made from aspen (Populus tremuloides Michx.), each with dimensions of 1 $\times 1 \times 4 \mathrm{~cm}($ radial $\times$ tangential $\times$ longitudinal $)$ with two to four annual growth rings per $\mathrm{cm}$, were allowed to incubate in situ through time. Stakes were collected four times ( 3 replicates per collection at each plot) after an initial collection (of 2 replicates) to determine correction factors to the initial wood weights taking into account the handling due to experimental set up and air dry to oven dry conversions. Stakes in boreal and temperate forests were collected once every year for four years (June 20032007), while stakes at the tropical sites were collected at 0.6 , $1.10,1.4$, and 2 years after placement in the field (2003-2005). A grand total of 4536 stakes were processed in this study $(972$ stakes per collection after the initial collection).

After field collection, all wood stakes were mailed to and processed at the International Institute of Tropical Forestry Chemical Laboratory in Puerto Rico. Once in the laboratory, stakes were oven dried at $65^{\circ} \mathrm{C}$ for at least a week and weighed after cleansing of any attached soil, litter or fungal debris. One of the three replicates per plot was then used to compare the performance of Young's Modulus of Elasticity (MOE) and stress tests on wood. Wood strength was measured parallel to grain under uniform and increasing unconfined compression on a Versa Loader (ELE International).

\section{Statistical Analyses}

Data were tested for homogeneity of variance by using the Levene's test of equality of error variances, and skewness (24). Log transformations were employed when the data did not meet the assumptions of normality. Annual decomposition rates $(k)$ were calculated using a single negative exponential decay model (25). A 5-way multivariate analysis of variance (MANOVA) was performed to determine the effect of climate (boreal, temperate, tropical), moisture (dry and moist forests), stand age and/or structure (open/young and closed/older), forest fragment size (small, medium and large), and position along the forest edge gradient/transect (outside, edge, and interior of the forest fragment) on the percent of mass remaining and decay constant (k) of aspen wood. In addition, analyses of variance (ANOVA) were used to determine the effect of moisture within a climatic region, through time, among fragment sizes, age / structure, and position along transects, on the percent of mass remaining and on MOE and stress. Two Student-Newman-Keuls (SNK) tests were used to compare the mean percent of mass remaining among the different forest fragment sizes and transect positions per climatic area. A simple linear correlation analysis (Pearson's Coefficient) was performed among the percent of mass remaining, decay constant, MOE and maximum load (stress) and fine woody debris categories $1-3\left(\mathrm{Mg} \mathrm{ha}^{-1}\right)(1,10$, and 100 hour fuels corresponding to categories of diameter sizes ranging from $0.25-0.60,0.61-2.5$, and $2.51-7.6 \mathrm{~cm}$, respectively), coarse woody debris (diameter $>7.61 \mathrm{~cm} ; \mathrm{Mg} \mathrm{ha}^{-1}$ ), total downed woody debris $\left(\mathrm{Mg} \mathrm{ha}^{-1}\right)$, number of tree stems per ha, basal area $\left(\mathrm{m}^{2} \mathrm{ha}^{-1}\right)$, tree species richness, mean annual precipitation, and fragment size area (ha).

\section{RESULTS}

There was a significant effect of climate (boreal, temperate, and tropical) on the percent of mass remaining and decay rate constant of aspen stakes (Table $1 ; \mathrm{P}<0.001$ for both variables). Overall, aspen stakes decayed fastest in the tropical sites, and the slowest in the temperate forest fragments. The percent of mass remaining of aspen stakes in boreal forests was intermediate to that of the tropical and temperate sites. After two years of decay in the field, on average, less than four percent of mass remaining was left at tropical sites, while after four years of incubation in the field on average about 83 and 89 percent of mass remaining was left in the boreal and temperate sites, respectively (Fig. 4). There was no significant direct effect of moisture on the percent of mass remaining as there was a significant interaction of climate and moisture on this variable 
Table 1. Results of five-way MANOVA for the effects of climate (C), moisture (M), age/structure (A), size (S), and position (P) on the percent of mass remaining and decay constant $(k)$ of aspen stakes. Results are not shown for the following significant 4-interactions: $C^{*} M^{*} A^{*} S, C^{*} M^{*} S^{*} P$, $M^{*} A^{*} S^{*} P$ and $k$. Significance is indicated in bold. All other three and four-way interactions are not significant at $\alpha=0.05 ; N=2562$.

\begin{tabular}{|c|c|c|c|c|c|c|c|}
\hline \multirow[b]{3}{*}{ Source } & \multirow[b]{3}{*}{ df } & \multicolumn{6}{|c|}{ Dependent variable } \\
\hline & & \multicolumn{3}{|c|}{ Mass remaining $(\%)^{a}$} & \multicolumn{3}{|c|}{ Decay constant $(k)^{b}$} \\
\hline & & $\mathbf{F}$ & $P$ & Power & $\mathbf{F}$ & $\boldsymbol{P}$ & Power \\
\hline Climate (C) & 2 & 4017.08 & 0.00 & 1.00 & 1496.77 & 0.00 & 1.00 \\
\hline Moisture (M) & 1 & 0.49 & 0.48 & 0.11 & 177.74 & 0.00 & 1.00 \\
\hline Age $(A)$ & 1 & 5.56 & 0.02 & 0.65 & 2.25 & 0.13 & 0.32 \\
\hline Size (S) & 2 & 8.20 & 0.00 & 0.96 & 39.31 & 0.00 & 1.00 \\
\hline Position (P) & 2 & 3.19 & 0.04 & 0.61 & 10.98 & 0.00 & 0.99 \\
\hline$C{ }^{*} M$ & 2 & 89.79 & 0.00 & 1.00 & 173.75 & 0.00 & 1.00 \\
\hline$C * A$ & 2 & 1.45 & 0.24 & 0.31 & 1.62 & 0.20 & 0.34 \\
\hline$C * S$ & 4 & 6.14 & 0.00 & 0.99 & 34.60 & 0.00 & 1.00 \\
\hline$C * P$ & 4 & 5.60 & 0.00 & 0.98 & 9.81 & 0.00 & 1.00 \\
\hline$C * M * S$ & 4 & 4.45 & 0.01 & 0.94 & 19.64 & 0.00 & 1.00 \\
\hline$C * A^{*} S$ & 4 & 8.35 & 0.00 & 0.99 & 21.51 & 0.00 & 1.00 \\
\hline$C * S^{*} P$ & 8 & 1.08 & 0.37 & 0.51 & 4.96 & 0.00 & 0.99 \\
\hline$M * A$ & 1 & 1.61 & 0.20 & 0.24 & 0.34 & 0.56 & 0.09 \\
\hline$M * S$ & 2 & 4.73 & 0.01 & 0.79 & 21.57 & 0.00 & 1.00 \\
\hline$M * P$ & 2 & 2.37 & 0.09 & 0.48 & 0.41 & 0.66 & 0.12 \\
\hline$M * A * S$ & 2 & 0.51 & 0.60 & 0.13 & 5.70 & 0.01 & 0.86 \\
\hline$M * S * P$ & 4 & 0.97 & 0.42 & 0.31 & 6.29 & 0.00 & 0.99 \\
\hline$A * S$ & 2 & 12.14 & 0.00 & 0.99 & 26.29 & 0.00 & 1.00 \\
\hline$A * P$ & 2 & .02 & 0.98 & 0.05 & 0.14 & 0.87 & 0.07 \\
\hline$A * S * P$ & 4 & 3.65 & 0.01 & 0.88 & 1.99 & 0.09 & 0.60 \\
\hline$S * P$ & 4 & 1.47 & 0.21 & 0.46 & 5.66 & 0.00 & 0.98 \\
\hline Error & 2454 & & & & & & \\
\hline
\end{tabular}

(Table 1). The percent of mass remaining was significantly greater in dry than in moist forests in boreal and temperate fragments, while the opposite was true for the tropical forest fragments (Fig. 4). Similarly, the decay rate constant was significantly lower, and the MOE, and the maximum stress of wood (Fig. 5) were significantly greater in the dry than in the moist forest fragments of the boreal and temperate areas. Decay rates of aspen stakes in the dry and moist boreal forests were $0.003 \mathrm{yr}^{-1}$ and $0.039 \mathrm{yr}^{-1}$, respectively. Decay rates of aspen stakes in dry and moist temperate forests were $0.002 \mathrm{yr}^{-1}$ and $0.021 \mathrm{yr}^{-1}$, respectively. In contrast, decay rates of aspen stakes in dry and moist tropical forests were $2.79 \mathrm{yr}^{-1}$ and $1.52 \mathrm{yr}^{-1}$, respectively. There was a significant effect of forest fragment size on the decay constant and percent of mass remaining (Table 1; $\mathrm{P}<0.001$ for both variables); overall and on average, small fragments had a greater percent of mass remaining (Fig. 6). Yet, when we analyze the data by climatic areas separately, different patterns emerge as there was also a significant interaction of climate and fragment size (Table 1; P $<0.001$ ), and a three-way interaction of climate, moisture and fragment size (Table $1 ; \mathrm{P}<0.001)$. There was no effect of fragment size on the percent of mass remaining of aspen stakes in the boreal sites, temperate dry, and tropical moist forests. Fragment size had a significant effect on the percent of mass remaining at the tropical dry and the moist temperate forests (Fig. 6). At the tropical dry forest, aspen stakes decayed slower in larger fragments than in either small or medium sized fragments, while at the moist temperate forests, the percent of mass remaining increased (decay decreased) as the size of the forest fragments increased as well (Fig. 6). Also, there was a significant climate and transect position (outside, edge or inside the fragment) interaction on the percent of mass remaining (Table 1). Transect position had no effect on the percent of mass remaining in the boreal forests but did have opposite effects in the temperate and tropical forest fragments. The percent of mass remaining was lowest in the outside position as compared to the edge and interior of a forest fragment in the temperate areas; while that position (outside) had the greatest percent of mass remaining in the tropical forest fragments (Fig. 7). The percent of mass remaining of aspen stakes were significantly correlated with MOE and the maximum stress of the wood (Table 2). Annual decay rates $(k)$ of aspen stakes did not correlate with MOE and the maximum stress of the wood. The percent of mass remaining and annual decay rates $(k)$ of aspen stakes were significantly and positively correlated with coarse woody debris, and total down woody debris, and negatively correlated with fine woody debris 1 and 2 ( 1 and 10 hours fuel loads), tree species richness and mean annual precipitation. In addition, there were significant negative correlations between mean annual precipitation and MOE and maximum stress (load) (Table 2).

\section{DISCUSSION}

The goal of this experiment was to examine whether the effects of forest fragmentation on wood decomposition rates vary in relation to fragment size, forest age (and/or structure), and climate at the macro- and meso-scales in boreal, temperate and tropical forests. In addition, we looked at how decay rates of wood vary relative to its position (outside, at the edge and center) along a non-forest/forest transition within forest fragments. We found that climate at the macro- (boreal, temperate, tropical) and meso-scales (dry vs. moist forests within a climatic region) significantly affected the decay rate of aspen stakes; and as expected decay rates were higher in wet/ warm climates than in cold/dry environments. The greater decay of wood in the tropical forest fragments as compared to the temperate and boreal can be explained by $i$ ) differences in mean annual precipitation (there was a significant correlations between the percent of mass remaining, the annual decay constant, MOE and maximum stress (load) and mean annual precipitation), and ii) the presence of particular functional groups of the soil fauna in the tropical region; in particular in the tropical dry forest. Moisture has been observed to have non linear effects on the decomposition of coniferous woods in laboratory experiments $(26,27)$ as low moisture levels decrease decay rates and saturated conditions can inhibit decomposer respiration (28). Field measurements also suggest that moisture is important in some ecosystems (28); but conflicting results for 

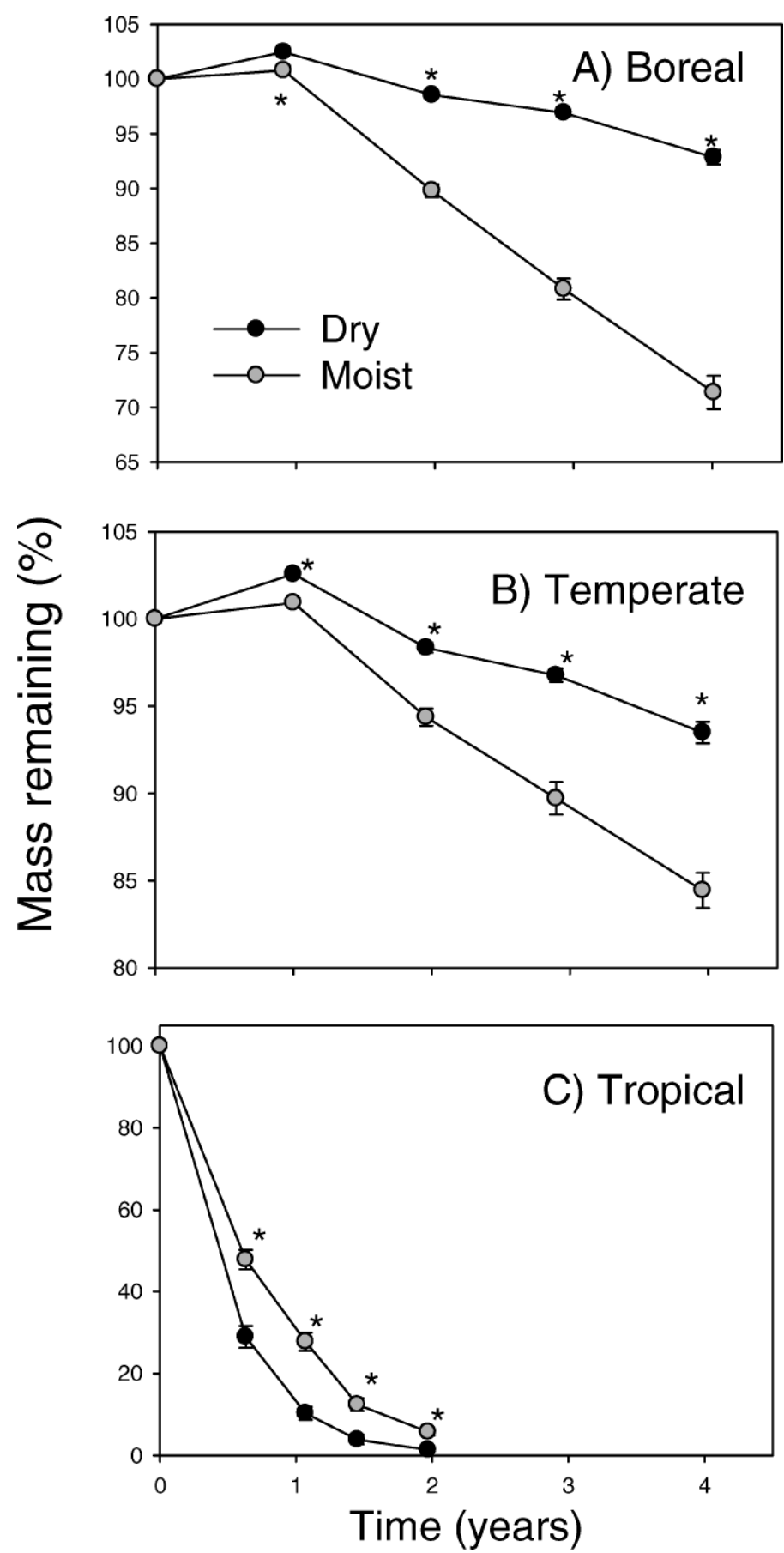

Figure 4. Changes in mass remaining ( \pm SE) of Populus tremuloides (aspen) stakes in A) boreal, B) temperate and C) tropical forest fragments. Asterisks indicate a significant effect of moisture condition within a climate region and day (one-way ANOVA; $\alpha=$ 0.05).

the relationship between wood decay and moisture are found in the literature. For example, Harmon et al. (29) found an inverse relationship between the decomposition rate of coarse woody debris in mixed conifer forests and annual precipitation (in a gradient ranging from $113-342 \mathrm{~cm} \mathrm{yr}^{-1}$ in precipitation) in the western US; a result consistent with laboratory studies that indicate excess moisture can reduce aeration (Harmon and Chen [30] as represented Yatskov et al. [28]). In contrast, Chambers et al. (31) tested for controls of decay on coarse-litter from major forested ecosystems worldwide (including temperate coniferous, deciduous, mixed, and tropical dry and evergreen forests), and found that precipitation was not correlated with decay rate constants but to mean annual temperature.
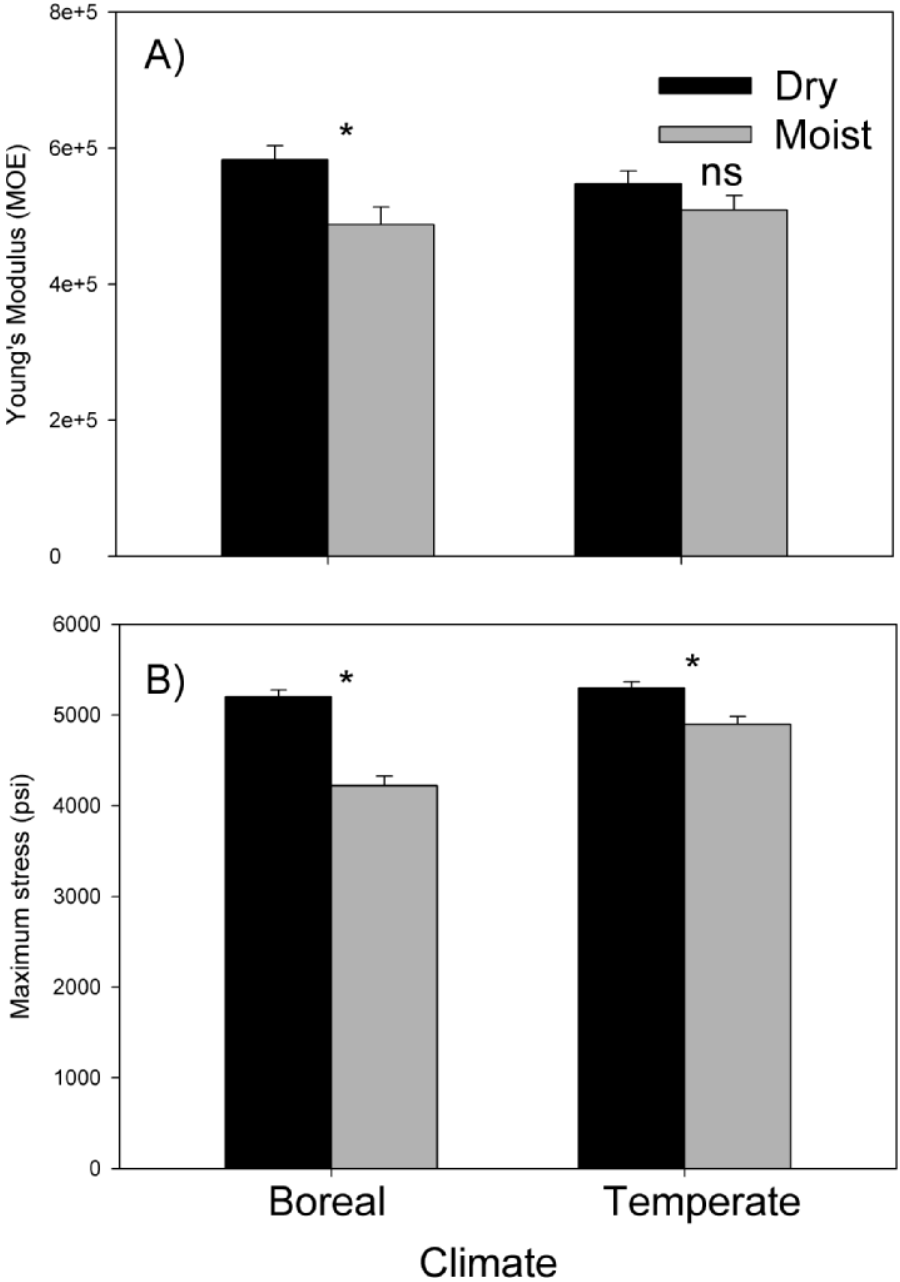

Figure 5. A) Young's Modulus of Elasticity (MOE) ( \pm SE), and B) Maximum Stress ( \pm SE) of Populus tremuloides (aspen) stakes in dry and moist boreal and temperate forest fragments. Asterisks indicate a significant moisture effect within a climate region; ns indicates no significant effect (MANOVA by forest type; $\alpha=0.05$ ).

Consistent with Chambers et al. (31), Marra and Edmonds (32) found that saturated conditions did not control seasonal variations of decay of coarse woody debris on a clear-cut forest in Washington, USA. In this study, we found that both the percent of mass remaining and the decay rate constant were significantly and negatively correlated to the annual precipitation. The percent of mass remaining was significantly greater in dry than in moist forest fragments in the boreal and temperate forests. Yet, the results of our study also showed a significant Climate and Moisture interaction on the decay rate constant; as the decay of aspen stakes was much higher in the dry than in the moist fragments in the tropical forests. Thus, our results support the contention that moisture condition is an important control over wood decomposition over broad climate gradients; and that such relationship (as also proven by laboratory studies) can have non linear effects given confounding factors associated with moisture regimes (e.g., air temperature, water potential of the wood, and inhabiting fauna among other variables).

Soil organisms have been shown to be important determinants of decomposition $(33,34)$. The fast decay rates of aspen wood in the tropical forest fragments can be explained by the conditioning of fungi in the wood (Fig. 8a, c), the presence of wood borrowing insects in the moist tropical (Fig. 8a) and the presence of termites (Fig. 8d-f) in the tropical dry forest fragments. Whitford et al. (35) and Schaefer et al. (36) showed that termites are capable of improving the microclimate and fragmentation of litter in arid ecosystems, resulting in faster 

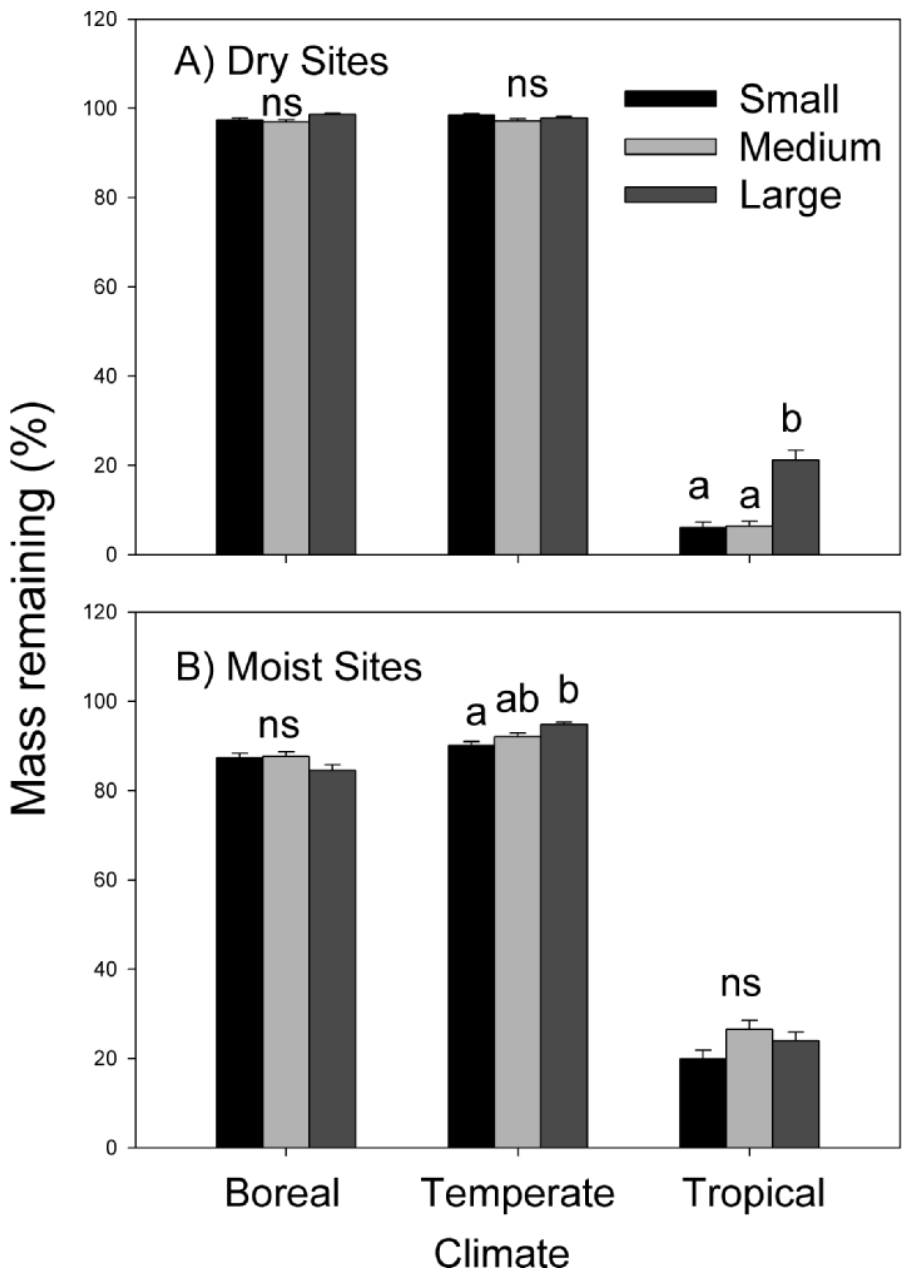

Figure 6. Mean mass remaining ( $\pm \mathrm{SE}$ ) of Populus tremuloides (aspen) stakes in small, medium and large A) dry and B) moist boreal, temperate, and tropical forest fragments. Common subscript letters within a climate region indicate no significant difference among fragment sizes using SNK (Student-Neuman-Keuls) test; ns indicates no significant effect; (ANOVA; $\alpha=0.05$ ).

decomposition rates than those predicted from previous models based on physico-chemical constraints on decay. The loss of this group, together with the general decline in abundance of macroinvertebrate decomposers, is hypothesized to reduce the ability of the fauna to uniformly affect decomposition rates in colder regions as well (37). Likewise, the results of this study support the contention that the presence of a particular group of organism (termites) can significantly alter the decay rates of wood more than what might be predicted based on climatic factors alone.

\section{Fragment Size}

Forest fragmentation alters ecological processes, but the generality of these effects is not yet known (38). Predictions about the effects of forest fragmentation on decomposition are difficult to make because fragmentation changes the key variables known to influence decay rates in contrasting ways: increasing litter quality in areas of secondary re-growth, having less favorable microclimatic conditions near forest edges, and unpredictably changing the soil biota (39). Comparisons of wood decay in fragments along broad climatic gradients are also difficult because controlled experiments looking at in situ decomposition of common wood substrates are not available. Results from our study imply that the relationship between forest fragment size and wood decomposition is complex; involving climatic interactions at the macro- and meso-scales

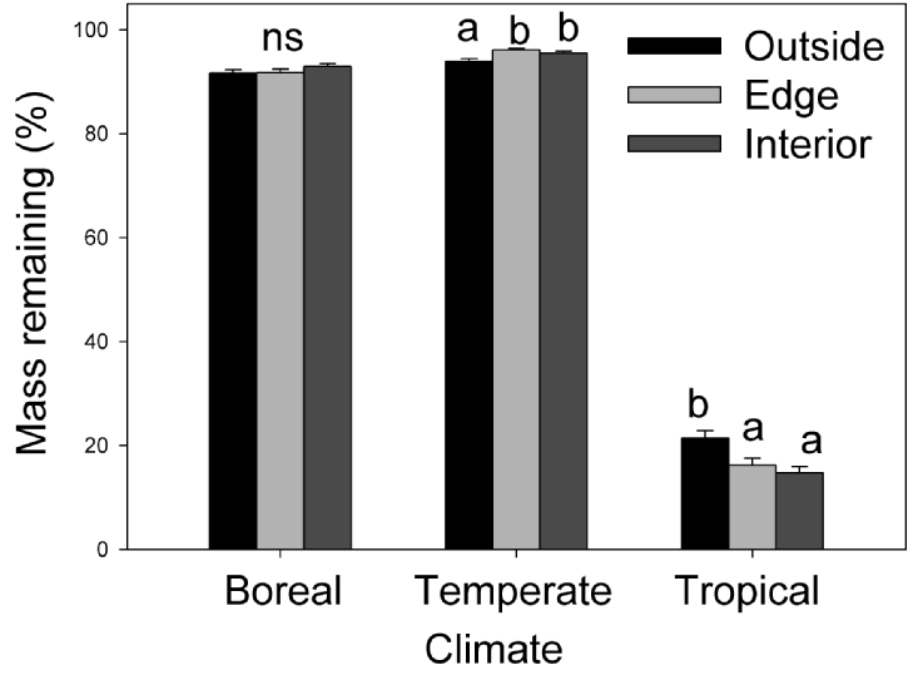

Figure 7. Mean mass remaining of Populus tremuloides (aspen) stakes as left to decompose outside, at the edge, and at the interior of moist boreal, temperate, and tropical forest fragments. Common subscript letters within a climate region indicate no significant difference among position along the edge gradient using SNK (Student-Neuman-Keuls) test; ns indicates no significant effect; (ANOVA; $\alpha=0.05$ ).

(Table 1) and potentially being explained by differences in the biota. Overall, the decay of aspen stakes was lower at smaller fragments as compared to medium and large forest fragments. Similarly, Didham (39) detected significantly slower leaf-litter decomposition in small ( $1 \mathrm{ha}$ ) forest fragments than in larger forest fragments in Amazonia suggesting it was the result from patchy distributions of decomposer invertebrates, particularly termites. Yet, when we compare differences in the decay of aspen stakes among fragment sizes within a climatic region and moisture regime, different patterns of wood decay emerged. The percent of mass remaining of aspen stakes was significantly lower (decayed faster) in small fragments than in larger fragments in the tropical dry and the temperate moist forests. Likewise, we can argue that the results for the tropical dry forest in this study could be explained by differences in the abundance and diversity of the decomposer organisms. For example, Souza and Brown (40) found that the guild composition of termites was altered in fragments, with an increase of wood-feeding types in smaller fragments. Further, they show that the habitatuse patterns of termites change in small fragments, from living in trees and ground nesting sites to a greater preference for rotting logs. In contrast, working at the tropical dry forest in Puerto Rico, Genet et al. (41) found that the composition of termite communities did not differ between dry forest fragments (on average $<100 \mathrm{ha}$ ) and the contiguous forest; and the decay of a native wood to be faster in the forest than in the fragments. However, they also found that the termite species present in most of their experimental woody bundles was absent from the sites that exhibited the slowest decay. Thus in this study, resource preference for aspen stakes (a high quality substrate) by termites may explain the fast decay rates observed in the tropical dry forests as related to the effects of fragment size and edges.

\section{Edge and Age Effects}

Micro-climatic gradients from clear-cut edges into forests stands are generally strong, changing considerably during the day and night, and seasons $(42,43)$. The changes in conditions from edges to forests can have different consequences on wood decomposition. Indeed, in this study we found a significant climate and position interaction effect on the decay on aspen 


\begin{tabular}{|c|c|c|c|c|c|}
\hline Variable & Statistic & PMR & $k$ & MOE & MAXLOAD \\
\hline$k$ & $\begin{array}{l}r(P) \\
N\end{array}$ & $\begin{array}{c}0.80(<0.01) \\
2562\end{array}$ & - & - & - \\
\hline MOE & $\begin{array}{l}r(P) \\
N\end{array}$ & $\begin{array}{c}0.15(<0.01) \\
815\end{array}$ & $\begin{array}{c}-0.05(0.19) \\
615\end{array}$ & - & - \\
\hline MAXLOAD & $\begin{array}{l}r(P) \\
N\end{array}$ & $\begin{array}{c}0.41(<0.01) \\
815\end{array}$ & $\begin{array}{c}0.08(0.06) \\
615\end{array}$ & $\begin{array}{c}0.51(<0.01) \\
814\end{array}$ & - \\
\hline FWD1 & $\begin{array}{l}r(P) \\
N\end{array}$ & $\begin{array}{c}-0.14(<0.01) \\
3718\end{array}$ & $\begin{array}{c}-0.11(<0.01) \\
2562\end{array}$ & $\begin{array}{c}0.01(0.72) \\
815\end{array}$ & $\begin{array}{c}0.03(0.38) \\
815\end{array}$ \\
\hline FWD2 & $\begin{array}{l}r(P) \\
N\end{array}$ & $\begin{array}{c}-0.11(<0.01) \\
3718\end{array}$ & $\begin{array}{c}-0.06(<0.01) \\
2562\end{array}$ & $\begin{array}{c}0.02(0.73) \\
815\end{array}$ & $\begin{array}{c}-0.01(0.71) \\
815\end{array}$ \\
\hline FWD3 & $\begin{array}{l}r(P) \\
\mathrm{N}\end{array}$ & $\begin{array}{c}0.02(0.21) \\
3718\end{array}$ & $\begin{array}{c}<0.01(0.78) \\
2562\end{array}$ & $\begin{array}{c}0.02(0.53) \\
815\end{array}$ & $\begin{array}{c}0.01(0.83) \\
815\end{array}$ \\
\hline CWD & $\begin{array}{l}r(P) \\
\mathrm{N}\end{array}$ & $\begin{array}{c}0.12(<0.01) \\
3718\end{array}$ & $\begin{array}{c}0.07(<0.01) \\
2562\end{array}$ & $\begin{array}{c}-0.02(0.64) \\
815\end{array}$ & $\begin{array}{c}0.07(0.06) \\
815\end{array}$ \\
\hline DWDT & $\begin{array}{l}r(P) \\
N\end{array}$ & $\begin{array}{c}0.11(<0.01) \\
3718\end{array}$ & $\begin{array}{c}0.06(<0.01) \\
2517\end{array}$ & $\begin{array}{c}-0.01(0.69) \\
815\end{array}$ & $\begin{array}{c}0.07(0.06) \\
815\end{array}$ \\
\hline NUM STEM & $\begin{array}{l}r(P) \\
N\end{array}$ & $\begin{array}{c}-0.11(<0.01) \\
3658\end{array}$ & $\begin{array}{c}-0.08(<0.01) \\
2517\end{array}$ & $\begin{array}{c}-0.03(0.44) \\
795\end{array}$ & $\begin{array}{c}-0.13(0.71) \\
795\end{array}$ \\
\hline BA & $\begin{array}{l}r(P) \\
N\end{array}$ & $\begin{array}{c}0.28(<0.01) \\
3758\end{array}$ & $\begin{array}{l}0.20(<0.01) \\
2517\end{array}$ & $\begin{array}{c}-0.01(0.78) \\
795\end{array}$ & $\begin{array}{c}-0.07(0.03) \\
795\end{array}$ \\
\hline SR & $\begin{array}{l}r(P) \\
N\end{array}$ & $\begin{array}{c}-0.19(<0.01) \\
3658\end{array}$ & $\begin{array}{c}-0.13(<0.01) \\
2535\end{array}$ & $\begin{array}{c}0.02(0.54) \\
795\end{array}$ & $\begin{array}{c}-0.10(<0.01) \\
795\end{array}$ \\
\hline PPTANN & $\begin{array}{l}r(P) \\
N\end{array}$ & $\begin{array}{c}-0.73(<0.01) \\
3718\end{array}$ & $\begin{array}{c}-0.46(<0.01) \\
2562\end{array}$ & $\begin{array}{c}-0.11(<0.01) \\
815\end{array}$ & $\begin{array}{c}-0.24(<0.01) \\
815\end{array}$ \\
\hline AREA & $\begin{array}{l}r(P) \\
\mathrm{N}\end{array}$ & $\begin{array}{c}-0.10(<0.01) \\
3718\end{array}$ & $\begin{array}{c}-0.08(<0.01) \\
2562\end{array}$ & $\begin{array}{c}-0.06(0.09) \\
815\end{array}$ & $\begin{array}{c}-0.07(0.05) \\
815\end{array}$ \\
\hline
\end{tabular}

wood stakes. There was no effect of position in the boreal forests, and the percent of mass remaining was the lowest and the highest in the outside position in the temperate and the tropical forest fragments, respectively; but no differences were found on the decay of aspen wood between edges and the interior of forest fragments. The results from the boreal forests in this study are similar to those reported by Snäll and Gunnar (44) for Swedish boreal forests. They found that spruce log quantity was higher near edges but neither the stage of decomposition nor log size was different between forest edges and interiors in 4-15 ha size patches. Similarly, although looking at leaf-litter decomposition, Vasconcelos and Laurance (45) did not find differences in fragment edges and the forests interior $(>250 \mathrm{~m}$ from the edges of primary forests) in central Amazonia. Further, the drier microclimatic conditions in fragment edges and second-growth forests ( $>10$ years old) did not appear to inhibit decomposition. Likewise, in this study, we did not find a significant effect of forest age (and/or structure) on the decay of aspen wood along the climatic gradient of boreal, temperate and tropical forests. Yet, Johnson and Greene (46) found that lodgepole pine and Engelmann spruce wood had a wide range of decay rates depending upon the age of the subalpine temperate forests in western Canada. Still, given the scarcity of literature of common substrate/wood decay experiments along conditions of clear-cut edges to forest interiors, it is difficult to make generalizations on the effects of fragmentation on fuel load decays along broad climatic gradients.

\section{MOE and Stress of Wood}

Wood decomposition is usually measured as a percent of mass loss (47), but this method may not be sensitive enough in northern climates were decay rates are slow. Jurgensen et al. (48) demonstrated that radial compression strength was a good indicator of initial decay of wood in cold boreal forests where decomposition is limited by low temperature and lack of oxygen or water; and where a rapid estimate of wood decomposition is wanted. In this study, significant differences in decay rates of aspen stakes were measured from dry and moist boreal forest fragments using the wood compression method. Measures of MOE and stress of aspen wood were significantly and positively correlated to the percent of mass remaining. However, fewer correlations were found for MOE and stress than for the percent of mass remaining and the decay constant to the biotic and abiotic variables (Table 2). The results from our study supports Jurgensen et al. (48) findings in which radial compression can provide good estimates of initial decay in cold environments but also indicate that the compression method might not be sensible enough to correlate with other biotic and abiotic variables when the percent of mass remaining does.

\section{CONCLUSION}

Numerous studies support that many ecological processes in forested ecosystems depend on the mass of woody tissue, and that its decay is relevant to the global balance of atmospheric $\mathrm{CO}_{2}$. Forest fragmentation (and associated edge effects) at the landscape scale have received increasing attention in ecology, conservation biology, and ecosystem management (42). Yet, comparative studies looking at the effect of fragmentation, edges, and forest age on wood decay are very sparse. Also, comparisons of wood decay in fragments along broad climatic gradients are difficult because controlled experiments looking at in situ decomposition of common wood substrates are not available. In this study, we found that $i$ ) moisture condition is an important control over wood decomposition over broad climate gradients; and that such relationship can be non linear, ii) the presence of a particular group of organism (termites) can significantly alter the decay rates of wood more than what might be predicted based on climatic factors alone, and iii) wood decay was not different between edges and interior forest fragments along this climatic gradient. Biotic controls on wood decay might be more important predictors of wood decay in tropical regions, while abiotic constraints seems to be important determinants of decay in cold forested fragments. 


\section{Tropical sites (after 231 days) Moist Dry}
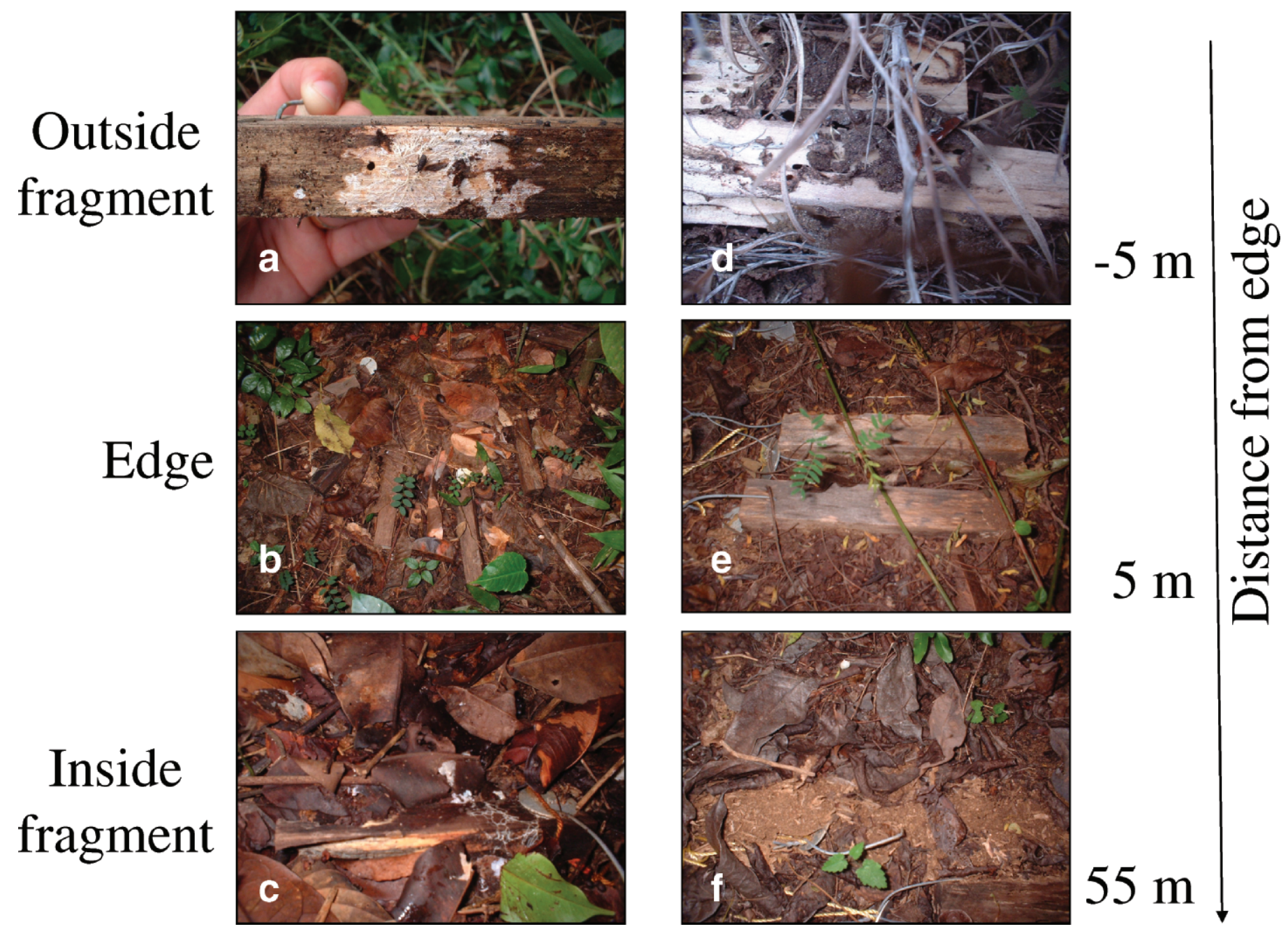

\section{Inside fragment}
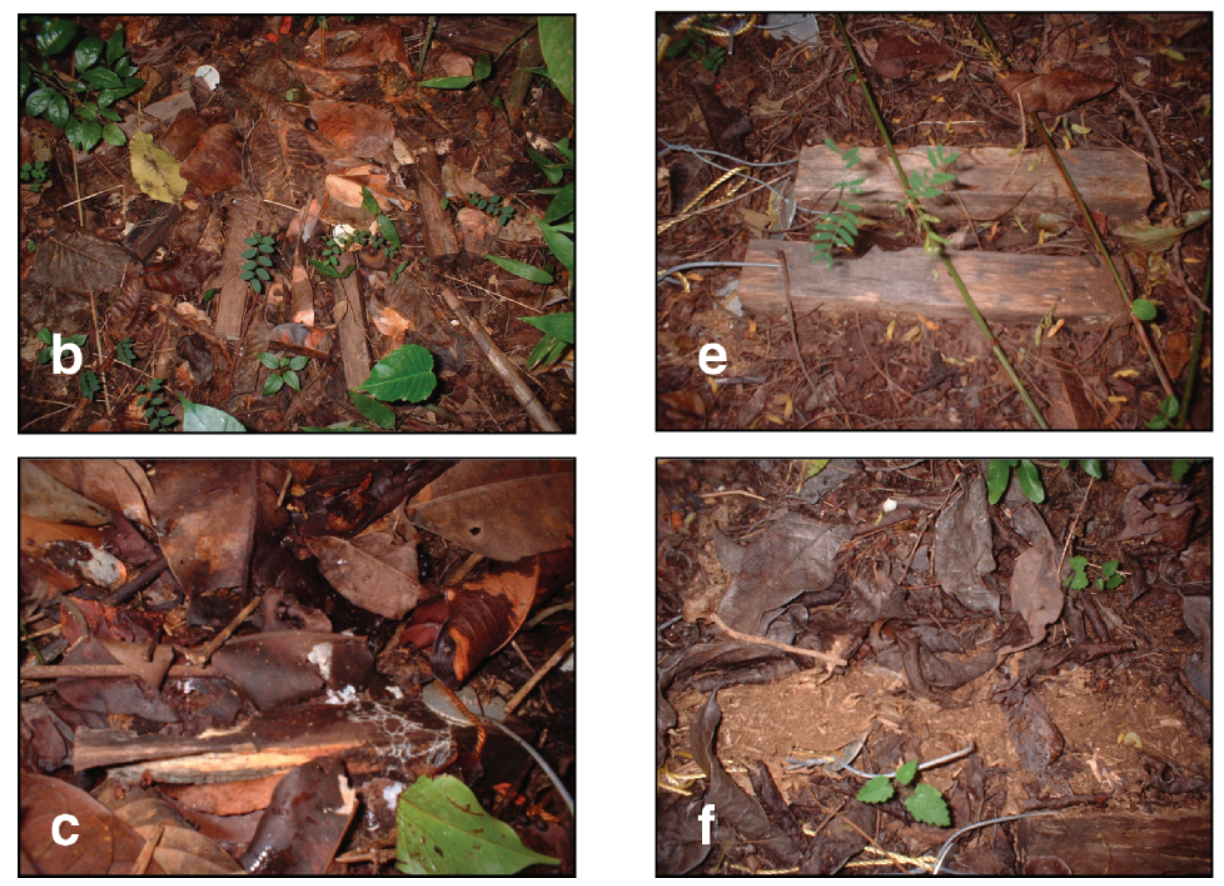

Figure 8. Populus tremuloides (aspen) stakes after about two years of decay outside, at the edge, and at the interior of moist (a-c) and dry (d-f) tropical forest fragments.

\section{References and Notes}

Saunders, D.A., Hobbs, R.J. and Margules, C.R. 1991. Biological consequences of ecosystem fragmentation: a review. Conserv. Biol. 5, 18-32.

Murcia, C. 1995. Edge effects in fragmented forests: implications for conservation. Trends Ecol. Evol. 10, 58-62.

Eva, H. and Lambin, E.F. 2000. Fires and land-cover change in the tropics: a remote sensing analysis at the landscape scale. J. Biogeogr. 27, 765-776.

4. Dale, V.H., Joyce, L.A., McNulty, S., Neilson, R.P., Ayres, M.P., Flannigan, M.D. Hanson, P.J., Irland, L.C., et al. 2001. Climate change can affect forests by altering frequency, intensity, duration, and timing of fire, drought, introduced species, insect and frequency, intensity, duration, and timing of fire, drought, introduced species, insect and
pathogen outbreaks, hurricanes, windstorms, ice storms, or landslides. BioScience 51, pathogen

5. Laurance, W.F., Lovejoy, T.E., Vasconcelos, H.L., Bruna, E.M., Didham, R.K., Stouffer, P.C., Gascon, C., Bierregaard, R.O., et al. 2002. Ecosystem decay of Amazonian forest fragments: a 22-year investigation, Conserv. Biol. 16, 605-618.

6. Laurance, W.F. and Bierregaard, R.O. 1997. Tropical Forest Remnants; Ecology, Management and Conservation of Fragmented Communities. University of Chicago Press, $616 \mathrm{pp}$.

Turner, M., Hargrove, W., Gardner, R. and Romme, W. 1994. Effects of fire on landscape heterogeneity in Yellowstone National Park, Wyoming. J. Veg. Sci. 5, 731742.

8. Zalamea-Bustillo, M. 2005. Soil biota, nutrients, and organic matter dynamics under decomposing wood. Master of Science in Tropical Biology Thesis, Department of Biology, Faculty of Natural Sciences, University of Puerto Rico, Río Piedras Campus, $117 \mathrm{pp}$.

9. Boddy, L. and Watkinson, S.C. 1995. Wood decomposition, higher fungi, and their role in nutrient redistribution. Can. J. Bot. 73, (Suppl. 1), S1377-S1383.

10. Brown, S., Schroeder, P. and Birdsey, R. 1997. Aboveground biomass distribution of US eastern hardwood forests and the use of large trees as an indicator of forest development. Forest Ecol. Manage. 96, 37-47.

11. Nascimento, H.E.M. and Laurance, W.F. 2002. Total aboveground biomass in central Amazonian rainforests: a landscape-scale. Forest Ecol. Manage. 168, 311-321.

12. Brown, S., Lugo, A.E. and Iverson, L.R. 1992. Processes and lands for sequestering carbon in the tropical forest landscape. Water Air Soil Poll. 64, 139-155.

13. Harmon, M.E. 2001. Carbon sequestration in forests: Addressing the scale question. $J$. Forest. 99, 24-29.
14. Jonsson, B.G. and Kruys, N. 2001. Ecology of Woody Debris in Boreal Forests. Ecological Bulletins No. 49. 283 pp.

15. Mellen, K., Marcot, B.G., Ohmann, J.L.,Waddell, K. L., Willhite, E.A., Hostetler, B B. Livingston, S.A. and Ogden, C. 2002. DecAID: A Decaying Wood Advisory Model for Oregon and Washington. USDA-FS. Gen. Tech. Rep. PSW-GTR-181, pp. 527-533.

16. Scholz O., Erickson, K and Azevedo, J. 2004. Restoring the Forest in a Young Coastal Douglas-fir Plantation. 16th International Conference, Society for Ecological Restoration, August 24-26, Victoria, Canada. (http://www galianoconservancy.ca/downloads restoration paper pdf

17. World Wildlife Fund (WWF). 2004. Dead Wood-Living Forests. WWF Report. (http:// www.panda.org/downloads/forests/deadwoodwithnotes.pdf)

18. Franklin, J.R., Shugart, H.H. and Harmon, M.E. 1987. Tree death as an ecological process. BioScience 37, 550-556.

19. Gould, W.A., González, G., Hudak, A.T., Hollingsworth, T.N. and Hollingsworth, J. 2008. Forest structure and downed woody debris in boreal, temperate, and tropical forest fragments. Ambio 37, 577-587.

20. Meddens, A.J.H., Hudak, A.T., Evans, J.S., Gould, W.A. and González, G. 2008 Characterizing forest fragments in boreal, temperate, and tropical ecosystems. Ambio 37, $569-576$.

21. Gould, W. A González, G and Carrero-Rivera, G. 2006. Structure and composition of vegetation along an elevational gradient in Puerto Rico, J. Veg. Sci. 17, 653-664.

22. Gould, W. A., Alarcón, C. Fevold, B., Jiménez, M.E., Martinuzzi, S., Potts, G., Solórzano, M. and Ventosa, E. 2007. Puerto Rico Gap Analysis Project-Final Report. USGS, Moscow, Idaho and the USDA Forest Service International Institute of Tropical Forestry, Río Piedras, PR. 159 pp.

23. USGS. 2003. National Atlas of the United States. (http://nationalatlas.gov)

24. SPSS. 2007. SPSS 16.0 for Windows. SPSS Chicago, Illinois.

25. Olson, J.S. 1963. Energy storage and the balance of producers and decomposers in ecological systems. Ecology 44, 322-331.

26. Chen, H. 1999. Root Decomposition in Three Coniferous Forests: Effects of Substrate Quality, Temperature, and Moisture. PhD Thesis, Department of Forest Science, Oregon State University, Corvallis, Oregon.

27. Hicks, W.I. 2000. Modeling Nitrogen Fixation in Dead Wood. PhD Thesis, Department of Forest Science, Oregon State University, Corvallis, Oregon.

28. Yatskov, M. Harmon, M.E and Krankina, O N. 2003 A chronosequence of wood decomposition in the boreal forests of Russia. Can. J. For. Res. 33, 1211-1226.

29. Harmon, M.E., Cromack, K. Jr. and Smith, B.J. 1987. Coarse woody debris in mixed conifer forests of Sequoia National Park. Can. J. For. Res. 24, 1883-1893. 
30. Harmon, M.E. and Chen, H. 1991. Coarse woody debris dynamics in two old-growth ecosystems: Changai Mountain Biosphere Reserve, People's Republic of China, and H.J. Andrews Experimental Forest, U.S.A. BioScience 41, 604-610.

31. Chambers, J.Q., Higuchi, N., Ferreira, L.V., Melack, J.M. and Schimel, J.P. 2000. Decomposition and carbon cycling of dead trees in tropical evergreen forests of the central Amazon. Oecologia 122, 380-388.

32. Marra, J.L. and Edmonds, R.L. 1996. Coarse woody debris and soil respiration in a clearcut on the Olymic Peninsul, Washington, U.S.A. Can. J. For. Res. 26, 1337-1345.

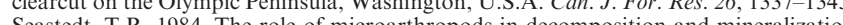
. $29,25-46$.

34. González, G. and Seastedt, T.R. 2001. Soil fauna and plant litter decomposition in tropical and subalpine forests. Ecology 82, 955-964.

35. Whitford, W.G., Meentemeyer, V., Seastedt, T.R., Cromack, K. Jr., Crossley, D.A. Jr., Santos, P., Todd, R.L. and Waide, J.B. 1981. Exceptions to the AET model: deserts and clear-cut forests. Ecology 62, 275-277.

36. Schaefer, D., Steinberger, Y. and Whitford, W.G. 1985. The failure of nitrogen an lignin control of decomposition in a North American desert. Oecologia 65, 382-386.

37. González, G. 2002. Soil organisms and litter decomposition. In: Modern Trends in Applied Terrestrial Ecology. Ambasht, R.S. and Ambasht, N.K. (eds), Kluwe Academic/Plenum Publishers, UK, 315-329.

38. Harrison, S. and Bruna, E.M. 1999. Habitat fragmentation and large-scale conservation: what do we know for sure? Ecography 22, 225-232.

39. Didham, R.K. 1998. Altered leaf-litter decomposition rates in tropical forest fragments. Oecologia 116, 397-406.

40. Souza, O.F.F. and Brown, V.K. 1994. Effects of habitat fragmentation on Amazonian termite communities. J. Trop. Ecol. 10, 197-205.

41. Genet, J.A., Genet, K.S., Burton, T.M., Murphy, P.C. and Lugo, A.E. 2001. Response of termite community and wood decomposition rates to habitat fragmentation in subtropical dry forest. Trop. Ecol. 42, 35-49.

42. Chen, J., Franklin, J.F. and Spies, T.A. 1995. Growing-season microclimatic gradient from clearcut edges into old-growth Douglas-fir forests. Ecol. Appl. 5, 74-86.

43. Renhorn, K., Esseen, P., Palmqvist, K. and Sundberg, B. 1997. Growth and vitality of epiphytic lichens I. Responses to microclimate along a forest edge-interior gradient Oecologia 109, 1-9.

44. Snäll, T. and Gunnar Jonsson, B. 2001. Edge effects on six polyporous fungi used as oldgrowth indicators in Swedish boreal forest. Ecol. Bull. 49, 255-262.

45. Vasconcelos, H.L and Laurance, W.F. 2005. Influence of habitat, litter type, and soil invertebrates on leaf-litter decomposition in a fragmented Amazonian landscape. Oecologia 144, 456-462.

46. Johnson, E.A. and Greene, D.F. 1991. A method for studying dead bole dynamics in Pinus contorta var. latifolia-Picea engelmannii forests. J. Veg. Sci. 2, 523-530.

47. Zabell, R.A. and Morrell, J.J. 1994. Wood Microbiology: Decay and Its Prevention Academic Press, San Diego.

48. Jurgensen, M., Reed, D., Page-Dumroese, D., Laks, P., Collins, A., Mroz, G. and Degórski, M. 2006. Wood strength loss as a measure of decomposition in northern forest mineral soil. Eur. J. Soil Biol. 42, 23-31.

49. Acknowledgments: This research was funded by the Joint Fire Science Program project entitled: "Landscape fragmentation and forest fuel accumulation: effects of fragmen size, age and climate" (JFSP Project Number 01-1-3-37). Grizelle González was also supported by grant DEB-0218039 from the National Science Foundation to the Institute of Tropical Ecosystem Studies, University of Puerto Rico (UPR), and the US. Department Ecos Agriculture-Forest Service (l Tropical Forestry (IIT ( Rodríguez, Ivan Vicens, Adriana Quijano, Gloriv Alberto García, Juan L. Ramírez, and Andrés Fernández fc and the field. Kasey Prestwich, Curtis Kvamme, and KC Murdock helped with fieldwork in Idaho, Washington, and Minnesota. Jamie Hollingsworth and Brian Charlton of the Bonanza Creek Long-Term Ecological Research program (BNZ-LTER) were instrumental at establishing the sites and retrieving samples from the field in Alaska. Humberto Robles and Elias Iglesias performed the wood compression test. We thank María M. Rivera for entry and quality control of the data. Maya Quiñones prepared figure 1, and help with the digital interpretation of forest fragment sizes. We
Grizelle González is a research ecologist at USDA Forest Service (FS), International Institute of Tropical Forestry (IITF), and adjunct faculty to the Department of Biology, University of Puerto Rico, Río Piedras Campus. Her interests are soil ecology / biology and terrestrial biogeochemistry. Her address: USDA Forest Service, International Institute of Tropical Forestry, 1201 Calle Ceiba, Río Piedras, Puerto Rico 009261115, USA.

E-mail: ggonzalez@fs.fed.us

William A. Gould is a landscape ecologist with the USDA FS IITF and adjunct faculty with the University of Idaho, Department of Rangeland Ecology and Management. He is investigating biodiversity, conservation, land cover and land use patterns and processes in tropical, temperate, and arctic biomes. He leads the Puerto Rico and U.S. Virgin Islands Gap Analysis Programs and the International Institute of Tropical Forestry GIS and Remote Sensing Laboratory. His address: USDA Forest Service, International Institute of Tropical Forestry, 1201 Calle Ceiba, Río Piedras, Puerto Rico 009261115, USA.

E-mail: wgould@fs.fed.us

Andrew T. Hudak is a Research Forester specializing in landscape-level applications of remote sensing for improved ecosystem management at the USDA Forest Service, Rocky Mountain Research Station, Moscow Forestry Sciences Laboratory. His address: USDA Forest Service, Rocky Mountain Research Station, 1221 South Main Street, Moscow, ID 83843, USA.

E-mail: ahudak@fs.fed.us

Teresa Nettleton Hollingsworth is a research ecologist at USDA FS, Boreal Ecology Cooperative Research Unit, Pacific Northwest Research Station. Her interests are plant community ecology, fire ecology, and vegetation mapping with a focus on boreal ecosystems. Her address: USDA Forest Service, Boreal Forest Cooperative Research Unit. Pacific Northwest Research Station, PO Box 756780, University of Alaska Fairbanks 99775, USA.

E-mail: thollingsworth@ @s.fed.us 